|Volume: 6 |Number: 2 |December 2021 |E-ISSN: 2503-4405 |P-ISSN: 2580-3441 |

\title{
The Effectiveness of an After-School English Program at a Community Childcare Center in Korea
}

\author{
Justin Suh', Alison Allen' ${ }^{2}$ Kyunghee Chae $^{3}$ \\ 1,2Asia Pacific International School, Seoul, Korea \\ ${ }^{3}$ Catholic university of Korea, Seoul, Korea \\ 1 jwsuh@apis.org, ${ }^{2}$ aallen@apis.org, ${ }^{3}$ chae9999@gmail.com
}

\begin{abstract}
Community childcare centers in Korea are established mainly for students from lowincome family for the purpose of protecting and educating children in the community. English program is one of the most important programs at the centers.This study investigated the effectiveness of an after-school English program at a community childcare center in a region of Seoul, Korea. Students registered in this English program were encouraged to participate in an online survey using a google form to fill out the questionnaire via a computer or mobile phone. Survey questions included the effectiveness of the program, students' satisfaction, and the most helpful class activity for learning English. A semi-structured interview was conducted to gather students' views on the program. Nine students who completed online survey volunteered for interview. Collected survey data were statistically analyzed using SAS Enterprise Guide 7.12. Final survey data set includes 11 respondents. The overall satisfaction with the after-school English program was high for both contents and effectiveness. High school students and student who participated in the program for more than six months chose the free conversation activity as the most helpful. The mean score for debates was the highest among all activities for English writing. The survey provided an opportunity for students to report their levels of satisfaction with the program. Results of this study indicate that students are satisfied with the English program at the community childcare centers overall and, that the performance of the lecturer can be categorized very well. This study provides insights into the need and direction of English education for students from low-income families. This study will serve as a basis to develop specialized and qualified English programs for successful English learning of low-income students, and facilitate the continuous improvement process.
\end{abstract}

Keywords:Community childcare center, Effectiveness, English program, Online survey, Satisfaction

\section{INTRODUCTION}

\section{Community Childcare Center in Korea}

Due to the International Monetary Fund (IMF) economic crisis in 1997, Korean has experienced the rise of unemployment and personal bankruptcy, leading to increases of family dissolution and poor families. Children from low-income families and single-parent families were neglected without proper parental protection, resulting in social problems such as various juvenile crimes. To solve these problems, study rooms have been operated 
at the private level, centering on urban slums. The Ministry of Health and Welfare began a national support by legislating these study room facilities as child welfare facilities called community childcare centers in 2004.

Community childcare centers are established and operated in accordance with Article 16, Paragraph 11 of the Child Welfare Act. These centers' role is to protect and educate children in the community, provide sound play and entertainment, and provide comprehensive child welfare services through connection with the community. The number of regional children's centers has steadily increased from 895 in 2004 to 4,107 today. However, there have been raised concerns about the qualitative growth of regional children's centers, which have rapidly increased in a short time.

To solve these problems, studies on community childcare centers has been actively conducted. Among these studies, the most covered research topic is on children and adolescents who use community childcare center centers (Choi, 2013). These studies have proven the role and importance of community childcare centers by analyzing children's abilities, school adaptation flexibility, psychosocial adaptation, and reduction of risk factors, and so on.

\section{English Program at The Community Childcare Center}

Since community childcare centers are operated mainly for low-income children who are difficult to receive extracurricular education, programs related to school subjects such as learning guidance, English programs, art, and music are most often implemented. After community childcare centers are institutionalized, various studies on community childcare centers have been conducted. These studies were mainly focused on actual conditions of these centers, satisfaction of students who use these centers, and revitalization and improvement plan of these centers (Byun \&Sim, 2016; Park, Park, and Lee, 2010). Although several studies have been conducted on various educational programs in community childcare center, studies on English programs offered by theses community childcare centers are very few (Kang, 2006; Kwon \& Yeoh, 2016; Kim \& Choi, 2015).

This is probably because it is difficult to plan and operate a systematic English program because community childcare centers do not have sufficient funds. In addition, most community childcare centers are operated on a small scale without government 
guidelines or generalized standard programs. Thus, there are differences in operating methods and programs depending on values and philosophy of the facility head (Yoon, Cho, \& Oh, 2013).

Currently, an English program, one of major educational programs of community childcare centers, offers basic English classes. Although there are differences between centers, the English program usually offers 1-2 lessons per week for a total of 2 hours. Since the instructor mainly relies on volunteers, the content and method of the class are inconsistent. They depend on the instructor's competence. Thus, the objective of this study was to investigate the satisfaction and effectiveness of an English program for students participating in the English program at a community childcare center in a region of Seoul, Korea. Results of this study will contribute to a provision of more advanced English programs.

\section{METHOD}

\section{Study Population}

The study population are secondary school students who have been participating in an after-school English program at community childcare center. Fifteen students were asked to answer a survey. Eleven completed questionnaires were received. Each respondent was paid a $\$ 3$ e-gift card for their participation.

\section{Online Survey}

The survey was conducted online via google form. We developed a google form for individuals to fill out the questionnaire via a computer or mobile phone. The URL (https://forms.gle/oK2VYpb3LfYPwDdVA) was distributed to individuals using a free mobile instant messagingapplication with free text and free call feature (KakaoTalk@) for both Android and iOS users.

The questionnaire consisted of three parts. The first part asked respondent's grade, gender, and participation period. The second part asked respondents for their perceptions of aspects in the program they considered useful. The purpose of the second part was to find out specific aspects of the program learners felt satisfied. The third part had items that measured learners' satisfaction with English program at community childcare center. 
The survey included a Likert scale, multiple choice, short-answer, and open-ended questions. The Likert scale for the questionnaire ranged from (1) strongly disagree to (5) strongly agree. A bilingual translator translated the questionnaire, originally written in English into Korean. Appropriate changes were made to both English and Korean versions of the questionnaire to make them compactible. The survey took less than 10 minutes to complete. It was available from November 17, 2020 to November 30, 2020.

\section{Interviews}

A semi-structured interview was conducted with nine students among who completed online survey and volunteered for interview. The overall purpose of each interview was to gather students' views on the program. The interview included questions on participants' purpose of English studying, experiences of the program, suggestions for improving the program, and so on. The interview questions are as follows:

1. Tell me about your experiences in the center's English program.

2. What are/were the most valuable learning experiences in the program?

3. How do you think the program has influenced your English learning?

4. What hardships have you been experiencing in the program?

5. What is the ultimate purpose of studying English?

6. How well do you think this program meets the needs of the students?

7. What do you think need improvement in this program?

Interviews were conducted from January 11, 2021 to April 30, 2021. The interview time per student was about 30 minutes. No comments were attributed to individuals. Norecord of names was taken or kept. Interviewees were told that these data gathered from the interviews might be used to prepare papers.

\section{Statistical Analyses}

Descriptive statistics was used to investigate the mean of students' responses and the distribution of students by gender and grade level (age). It was also used to determine levels of satisfaction with contents of class. Student's t-test and analysis of variance (ANOVA) were performed to analyze the overall satisfaction of learning English program according to participants' characteristics and the effect of each class activity on English speaking, English listening, English reading, and English writing.

\section{4 |ENGLISH EDUCATION}

Journal of English Teaching and Research 
If data did not follow a normal distribution, Mann-Whitney $U$ test and Wilcoxon rank sum test were used. Categorical variables were compared using the $\chi^{2}$ test. All statistical analyses were performed using SAS Enterprise Guide 7.12. Statistical significance was set at $\mathrm{p}<0.05$ for all analyses.

\section{Ethical Statement}

Ethics approval for this study was obtained from the Institutional Review Board (IRB) of Seoul St. Mary's Hospital (MC21QISI0054). Before completing the survey, participants were given a brief introduction to the purpose and aims of the survey. They were asked to confirm (clicking a box) if they were willing to proceed. All responses were treated anonymously and confidentially.

\section{RESULTS}

\section{Study Population}

Of 15 students who participated in the English program at the community childcare center, 11 (73.3\%) completed the questionnaire. Table 1 shows general characteristics of overall respondents. Regarding grade levels of respondents, $36.4 \%$ of respondents were in the $7^{\text {th }}$ grade, $9.1 \%$ in the $8^{\text {th }}$ grade, $18.2 \%$ in the $9^{\text {th }}$ grade, and $36.4 \%$ in the $10^{\text {th }}$ grade. Most (54.6\%) of respondents were females. The proportion of respondents who participated in the program for six months to one year was the highest (at $45.5 \%$ ). 
Table 1. Characteristics of participants

\begin{tabular}{|c|c|c|c|}
\hline & & $\mathbf{N}$ & $\%$ \\
\hline & \multirow[t]{2}{*}{ Total } & & \\
\hline & & 11 & 100 \\
\hline \multirow{5}{*}{ Grade level } & $7^{\text {th }}$ & 4 & 36.4 \\
\hline & $8^{\text {th }}$ & 1 & 9.1 \\
\hline & & & \\
\hline & $9^{\text {th }}$ & 2 & 18.2 \\
\hline & $10^{\text {th }}$ & 4 & 36.4 \\
\hline \multirow{2}{*}{ Gender } & Male & 5 & 45.5 \\
\hline & Female & 6 & 54.6 \\
\hline \multirow{3}{*}{ Participation period } & Three months or less & 3 & 27.3 \\
\hline & Six months to one year & 5 & 45.5 \\
\hline & More than three years & 3 & 27.3 \\
\hline
\end{tabular}

\section{Survey Results}

Table 2 shows students' satisfaction on the English program by grade level, gender, and participation periods. Because of the small number of respondents, the grade level was divided into two groups, G7/8 and G9/10. Students who participated in the program for more than three years showed higher satisfaction on the understanding of the topic in class $(p=0.0083)$. The mean score for the effectiveness of the program was also higher for those with a longer participation period. 
|Volume: 6 |Number: 2 |December 2021 |E-ISSN: 2503-4405 |P-ISSN: 2580-3441 |

Table 2. Satisfaction by grade level, gender, and participation period

\begin{tabular}{|c|c|c|c|c|c|c|c|c|c|c|c|}
\hline & \multirow{2}{*}{$\begin{array}{l}\text { Total, } \\
\text { mean } \\
(\mathrm{SD})\end{array}$} & \multicolumn{3}{|c|}{ Grade level } & \multicolumn{3}{|c|}{ Gender } & \multicolumn{4}{|c|}{ Participation period } \\
\hline & & G7_8 & G9_10 & Pvalue & $\mathbf{F}$ & $\mathbf{M}$ & $\begin{array}{c}P \\
\text { value }\end{array}$ & $\begin{array}{c}3 \\
\text { months } \\
\text { or less } \\
\end{array}$ & $\begin{array}{l}\text { 6month } \\
s \text { to } 1 \\
\text { year }\end{array}$ & $\begin{array}{l}\text { More } \\
\text { than } 3 \\
\text { years }\end{array}$ & Pvalue \\
\hline The contents of English program & 11 & $5(45.5)$ & $6(54.5)$ & & $5(45.5)$ & $6(54.5)$ & & $3(27.3)$ & $5(45.5)$ & $3(27.3)$ & \\
\hline $\begin{array}{l}\text { I deepened my understanding of the } \\
\text { topics we discussed in the course }\end{array}$ & $4.3(0.8)$ & $4.2(1.1)$ & $4.3(0.5)$ & 0.7957 & $4.6(0.5)$ & $4.0(0.9)$ & 0.2247 & $3.3(0.6)$ & $4.4(0.5)$ & $5.0(0.0)$ & 0.0083 \\
\hline Class time is appropriate & $4.6(0.7)$ & $4.4(0.9)$ & $4.8(0.4)$ & 0.3129 & $4.8(0.4)$ & $4.5(0.8)$ & 0.4917 & $4.3(1.2)$ & $4.8(0.4)$ & $4.7(0.6)$ & 0.6837 \\
\hline Class size is appropriate & $4.5(0.7)$ & $4.6(0.9)$ & $4.3(0.5)$ & 0.5503 & $4.6(0.5)$ & $4.3(0.8)$ & 0.5503 & $4.0(1.0)$ & $4.6(0.5)$ & $4.7(0.6)$ & 0.4476 \\
\hline $\begin{array}{l}\text { The activities in class are interesting and } \\
\text { fun }\end{array}$ & $4.4(0.8)$ & $4.2(0.8)$ & $4.5(0.8)$ & 0.5683 & $4.6(0.5)$ & $4.2(1.0)$ & 0.4048 & $4.0(1.0)$ & $4.4(0.9)$ & $4.7(0.6)$ & 0.6454 \\
\hline $\begin{array}{l}\text { The teacher's feedback helped me to } \\
\text { understand what skills I needed to use more }\end{array}$ & $4.5(0.8)$ & $4.2(1.1)$ & $4.7(0.5)$ & 0.3749 & $4.2(0.8)$ & $4.7(0.8)$ & 0.3749 & $4.3(1.2)$ & $4.6(0.5)$ & $4.3(1.2)$ & 0.8896 \\
\hline $\begin{array}{l}\text { The teacher gave clear instructions for } \\
\text { using skills and completing activities }\end{array}$ & $4.7(0.6)$ & $4.6(0.9)$ & $4.8(0.4)$ & 0.579 & $5.0(0.0)$ & $4.5(0.8)$ & 0.2181 & $4.3(1.2)$ & $4.8(0.4)$ & $5.0(0.0)$ & 0.4723 \\
\hline \multicolumn{12}{|l|}{ The effectiveness of English program } \\
\hline $\begin{array}{l}\text { After taking English class, I am able to } \\
\text { speak in English better }\end{array}$ & $4.0(1.0)$ & $4.0(1.0)$ & $4.0(1.1)$ & 1 & $4.0(1.0)$ & $4.0(1.1)$ & 1 & $3.0(0.0)$ & $4.6(0.9)$ & $4.0(1.0)$ & 0.0731 \\
\hline $\begin{array}{l}\text { After taking English class, I am able to } \\
\text { understand spoken English better }\end{array}$ & $4.4(0.9)$ & 4. (1.1) & $4.5(0.8)$ & 0.6184 & $4.4(0.9)$ & $4.3(1.0)$ & 0.9125 & 3.7 (1.2) & $4.6(0.9)$ & $4.7(0.6)$ & 0.3417 \\
\hline $\begin{array}{l}\text { This English program help me to do } \\
\text { school work better }\end{array}$ & $4.4(0.7)$ & $4.2(0.8)$ & $4.5(0.5)$ & 0.4917 & $4.6(0.5)$ & $4.2(0.8)$ & 0.3129 & $3.7(0.6)$ & $4.6(0.5)$ & $4.7(0.6)$ & 0.0965 \\
\hline $\begin{array}{l}\text { This English program gave me } \\
\text { confidence in English }\end{array}$ & $4.0(1.1)$ & $3.8(1.3)$ & $4.2(1.0)$ & 0.6072 & $4.4(0.9)$ & $3.7(1.2)$ & 0.2919 & $2.7(0.6)$ & $4.4(0.9)$ & $4.7(0.6)$ & 0.0204 \\
\hline $\begin{array}{l}\text { Through this English program, I have } \\
\text { improved my overall English language } \\
\text { proficiency }\end{array}$ & $4.2(1.0)$ & $4.2(1.1)$ & $4.2(1.0)$ & 0.9587 & $4.4(0.9)$ & $4.0(1.1)$ & 0.5299 & $3.0(0.0)$ & $4.6(0.9)$ & $4.7(0.6)$ & 0.0259 \\
\hline $\begin{array}{l}\text { After taking English class, my English } \\
\text { reading skills have improved }\end{array}$ & $4.2(0.9)$ & $4.0(1.0)$ & $4.3(0.8)$ & 0.5571 & $4.4(0.5)$ & $4.0(1.1)$ & 0.479 & $3.0(0.0)$ & $4.8(0.4)$ & $4.3(0.6)$ & 0.0014 \\
\hline $\begin{array}{l}\text { After taking English class, my English } \\
\text { writing skills have improved }\end{array}$ & $4.2(1.0)$ & $4.2(1.1)$ & $4.2(1.0)$ & 0.9587 & $4.4(0.9)$ & $4.0(1.1)$ & 0.5299 & $3.0(0.0)$ & $4.6(0.9)$ & $4.7(0.6)$ & 0.0259 \\
\hline
\end{tabular}


Table 3 shows the most helpful class activity among free conversation, debates, word matching game, vocabulary explanation, and book discussion. The most helpful activity was 'Free conversation'. Especially high school students (G9/10) and student who participated in the program for more than 6 months chose this free conversation activity as being the most helpful

Table 3. Most helpful activity

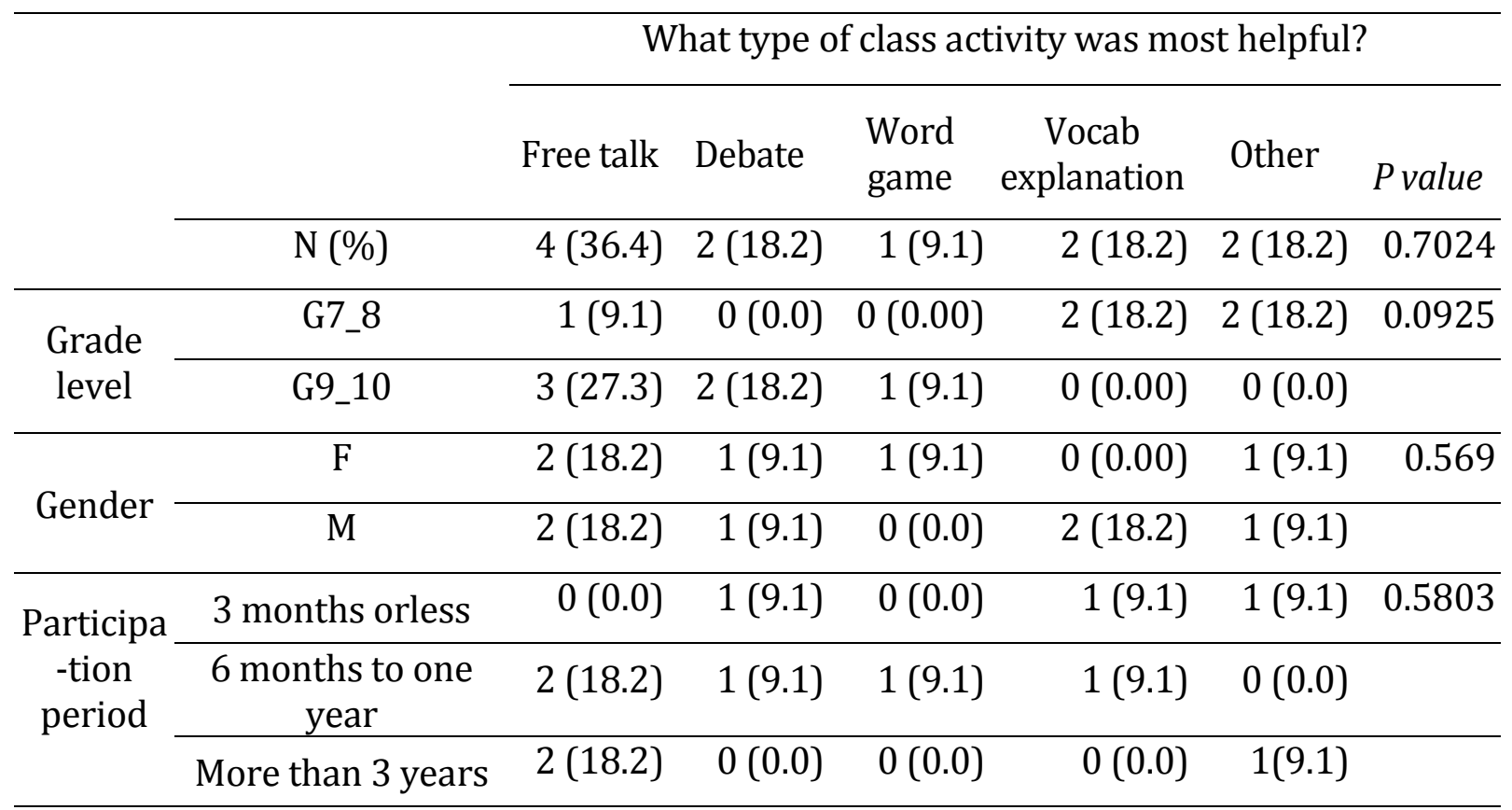

Table 4 shows the most helpful activity for each category of English learning such as speaking, listening, reading, and writing. Vocabulary explanation was the most helpful activity for speaking, listening, and reading (mean score: 4.5, SD: 0.69). The number of high school students who responded that vocabulary explanation was the most helpful in improving their listening skills, was higher than that of middle school students $(p=$ 0.0366).

Interestingly, the mean score for debates was the highest among other activities in English writing. It could be assumed that the activity of organizing and writing ideas for debate helped students improve their writing skills. The longer the participation period, the higher the average score for each activity. 
|Volume: 6 |Number: 2 |December 2021 |E-ISSN: 2503-4405 |P-ISSN: 2580-3441 |

Table 4. Most helpful activity in each category

\begin{tabular}{|c|c|c|c|c|c|c|c|c|c|c|c|}
\hline & & \multirow{3}{*}{$\begin{array}{c}\text { Sum } \\
\text { (mean, SD) }\end{array}$} & \multicolumn{3}{|c|}{ Grade level } & \multicolumn{2}{|c|}{ Gender } & \multicolumn{4}{|c|}{ Participation period } \\
\hline & & & G7/8 & G9/10 & $\begin{array}{c}P \\
\text { value }\end{array}$ & $\mathrm{F}$ & M & $\begin{array}{c}3 \text { months } \\
\text { or less }\end{array}$ & $\begin{array}{l}6 \text { months } \\
\text { to } 1 \text { year }\end{array}$ & $\begin{array}{c}\text { More than } \\
3 \text { years }\end{array}$ & $\begin{array}{c}P \\
\text { value }\end{array}$ \\
\hline & & & $5(45.5)$ & $6(54.5)$ & & $5(45.5)$ & $6(54.5)$ & $3(27.3)$ & $5(45.5)$ & $3(27.3)$ & \\
\hline \multirow{5}{*}{$\begin{array}{l}\text { English } \\
\text { speaking }\end{array}$} & Free conversation & $4.09(1.22)$ & $3.80(1.30)$ & $4.33(1.21)$ & 0.4999 & $4.40(1.34)$ & $3.83(1.17)$ & $3.00(1.00)$ & $4.20(1.30)$ & $5.00(0.00)$ & 0.1214 \\
\hline & Debates & $4.36(0.81)$ & $4.00(1.00)$ & $4.67(0.52)$ & 0.1864 & $4.60(0.55)$ & $4.17(0.98)$ & $3.33(0.58)$ & $4.80(0.45)$ & $4.67(0.58)$ & 0.0113 \\
\hline & Word game & $4.36(1.03)$ & $4.00(1.41)$ & $4.67(0.52)$ & 0.3078 & $4.80(0.45)$ & $4.00(1.26)$ & $3.00(1.00)$ & $4.80(0.45)$ & $5.00(0.00)$ & 0.005 \\
\hline & Vocab explanation & $4.55(0.69)$ & $4.40(0.89)$ & $4.67(0.52)$ & 0.5503 & $4.80(0.45)$ & $4.33(0.82)$ & $3.67(0.58)$ & $4.80(0.45)$ & $5.00(0.00)$ & 0.0093 \\
\hline & Book discussion & $4.09(0.94)$ & $4.00(1.00)$ & $4.17(0.98)$ & 0.7874 & $4.00(1.00)$ & $4.17(0.98)$ & $3.33(0.58)$ & $4.60(0.89)$ & $4.0(1.00)$ & 0.188 \\
\hline \multirow{5}{*}{$\begin{array}{l}\text { English } \\
\text { listening }\end{array}$} & Free conversation & $4.27(1.10)$ & $3.80(1.30)$ & $4.67(0.82)$ & 0.2103 & $4.40(0.89)$ & $4.17(1.33)$ & $3.33(1.53)$ & $4.60(0.89)$ & $4.67(0.58)$ & 0.2408 \\
\hline & Debates & $4.27(1.10)$ & $4.00(1.41)$ & $4.50(0.84)$ & 0.4837 & $4.60(0.89)$ & $4.00(1.26)$ & $3.00(1.00)$ & $4.60(0.89)$ & $5.00(0.00)$ & 0.0332 \\
\hline & Word game & $4.18(1.08)$ & $3.60(1.14)$ & $4.67(0.82)$ & 0.1039 & $4.20(0.84)$ & $4.17(1.33)$ & $3.33(1.53)$ & $4.60(0.89)$ & $4.33(0.58)$ & 0.2892 \\
\hline & Vocab explanation & $4.45(0.69)$ & $4.00(0.71)$ & $4.83(0.41)$ & 0.0366 & $4.40(0.55)$ & $4.50(0.84)$ & $4.00(1.00)$ & $4.80(0.45)$ & $4.33(0.58)$ & 0.2892 \\
\hline & Book discussion & $4.09(0.94)$ & $4.00(1.00)$ & $4.17(0.98)$ & 0.7874 & $4.00(1.00)$ & $4.17(0.98)$ & $3.33(0.58)$ & $4.60(0.89)$ & $4.00(1.00)$ & 0.188 \\
\hline \multirow{5}{*}{$\begin{array}{l}\text { English } \\
\text { reading }\end{array}$} & Free conversation & $4.27(1.10)$ & $4.00(1.41)$ & $4.50(0.84)$ & 0.4837 & $4.60(0.89)$ & $4.00(1.26)$ & $3.00(1.00)$ & $4.60(0.89)$ & $5.00(0.00)$ & 0.0332 \\
\hline & Debates & $4.27(0.90)$ & $4.00(1.00)$ & $4.50(0.84)$ & 0.3893 & $4.40(0.89)$ & $4.17(0.98)$ & $3.33(0.58)$ & $4.60(0.89)$ & $4.67(0.58)$ & 0.0942 \\
\hline & Word game & $4.36(1.12)$ & $4.00(1.41)$ & $4.67(0.82)$ & 0.3522 & $4.60(0.89)$ & $4.17(1.33)$ & 3.33 (1.53) & $4.60(0.89)$ & $5.00(0.00)$ & 0.1546 \\
\hline & Vocab explanation & $4.55(0.69)$ & $4.40(0.89)$ & $4.67(0.52)$ & 0.5503 & $4.80(0.45)$ & $4.33(0.82)$ & $3.67(0.58)$ & $4.80(0.45)$ & $5.00(0.00)$ & 0.0093 \\
\hline & Book discussion & $4.18(0.98)$ & $4.00(1.00)$ & $4.33(1.03)$ & 0.6019 & $4.00(1.00)$ & $4.33(1.03)$ & 3.67 (1.15) & $4.60(0.89)$ & $4.00(1.00)$ & 0.4441 \\
\hline \multirow{5}{*}{$\begin{array}{l}\text { English } \\
\text { writing }\end{array}$} & Free conversation & $4.27(1.01)$ & $4.20(1.10)$ & $4.33(1.03)$ & 0.8402 & $4.60(0.89)$ & $4.00(1.10)$ & $3.00(0.00)$ & $4.60(0.89)$ & $5.00(0.00)$ & 0.0098 \\
\hline & Debates & $4.36(0.92)$ & $4.20(1.10)$ & $4.50(0.84)$ & 0.6184 & $4.60(0.89)$ & $4.17(0.98)$ & $3.33(0.58)$ & $4.60(0.89)$ & $5.00(0.00)$ & 0.0419 \\
\hline & Word game & $4.18(1.17)$ & $4.00(1.41)$ & $4.33(1.03)$ & 0.6618 & $4.60(0.89)$ & $3.83(1.33)$ & $2.67(0.58)$ & $4.60(0.89)$ & $5.00(0.00)$ & 0.0065 \\
\hline & Vocab explanation & $4.27(0.90)$ & $4.00(1.00)$ & $4.50(0.84)$ & 0.3893 & $4.40(0.89)$ & $4.17(0.98)$ & $3.33(0.58)$ & $4.80(0.45)$ & $4.3(1.15)$ & 0.0651 \\
\hline & Book discussion & $4.18(0.98)$ & $4.20(1.10)$ & $4.17(0.98)$ & 0.9587 & $4.20(1.10)$ & $4.17(0.98)$ & $3.33(0.58)$ & $4.60(0.89)$ & $4.33(1.15)$ & 0.2113 \\
\hline
\end{tabular}


|Volume 6 |Number 2 |December 2021 |E-ISSN: 2503-4405 |P-ISSN: 2580-3441|

\section{Interview Results}

Students' responses to the above questions were categorized into roughly three responses for each question. All 9 students responded that it was a good experience to participate in the center's English program. The most valuable experience by participating in the program was that the class size was small. Thus, there were many opportunities to speak. In addition, the atmosphere was supportive, not competitive. Therefore, they felt that learning English was fun.

Regarding the impact of the center's program on English learning, students were no longer afraid to speak in English. They learned English listening, speaking, reading, and writing in a balanced way and they felt that school English classes became fun. All students responded that the program was not difficult.

Regarding students' ultimate goal of studying English, the majority (2/3) of them wanted to go to a good university. For the purpose of studying English, the program at the center provided more opportunity to speak English than in school English class so that they could speak comfortably without feeling embarrassment even if they were not good at it. They could learn it by listening what others said. When asked about how to improve current English program, one third of students suggested dividing the class according to individual English level.

\section{DISCUSSION}

The aim of this study was to investigate the satisfaction and effectiveness of an afterschool English program at a community childcare center in a region of Seoul, Korea. The ultimate goal was to provide a systematic and improved instruction tailored to the needs of students based on students' goals of English learning. Effective teaching methods were also investigated through online surveys and in-depth interviews.

\section{Principle Findings}

In general, the longer the students participated in the center's English program, the higher their satisfaction with the class. Through the interview survey, it was found that students needed different classes according to their English levels. For high school students, debate was the most effective activity for reading and writing. Vocab explanation was helpful for almost all areas of English learning. The level of difficulty of vocabulary 
might need to be adjusted according to students' grade levels or English levels. For beginners or students in lower grades, it would be more effective to start studying basic vocabulary before focusing on speaking. Book discussion activity was the least popular activity for both middle and high school students.

In studies about English teaching methods in Korean schools, classes for elementary school students use activity-centered and communication-oriented teaching methods, while grammar, reading comprehension, and vocabulary-oriented education are mainly conducted in middle school classes (Kim, 2010). Although the goal of Korean middle school English education is to improve fluency and communication skills, in reality, middle school English classes are focused on grammar and reading comprehension (Kim, 2006). According to the results of student interviews, the ultimate goal of most students for participating in the center's English program was to improve their English scores and enter a good university. Thus, classes for high school students are needed to help them achieve this goal.

\section{Evaluation of English Program}

We also investigated the definition and method of program evaluation through domestic and international research and applied this to the satisfaction survey of the community childcare center's after-school English program. Similar to evaluation for other programs, the evaluation of language program involves a process of data collection, analysis, and synthesis. Its purpose is to analyze and comprehensively improve each element of the curriculum in continuous program operation (Brown, 2001).

In addition, surveys play an essential role in analyzing the needs of a program and evaluating its effectiveness. Therefore, to run a program effectively, it is necessary to investigate the perception and satisfaction of participants in the program. In particular, the best way to survey the perception of language programs is through direct interviews or surveys. Therefore, in-depth surveys are important to find out the effectiveness and satisfaction of after-school English programs.

One of ways to measure the effectiveness of a language program is to identify which instructional method is the most effective (Ellis, 2013). Comparing statistics between groups is also another good way to analyze various factors for the effectiveness of classes. (Palardy\&Rumberger, 2004). In particular, differences in statistical variables between 
groups by class can be seen as a more important factor than various variables such as differences in institutions.

Many studies have performed satisfaction survey and performance evaluations of afterschool programs (Behrman, et al., 2020; McDavid, et al., 2020; Mehta, et al., 2018).Due to the nature of an after-school program, subjects and the participants of the program are not limited to English or specific age groups. They are diverse, including elementary, middle, and high school students.

This study showed a positive correlation between the duration of program participation and student satisfaction. Previous studies on the duration of participation in the program and learning outcomes have been reported. The Afterschool Alliance, a nonprofit public awareness and advocacy organization supported by a group of public, private, and nonprofit institutions has evaluated the effectiveness of the BEST (Better Educated Students for Tomorrow) program, one of the representative afterschool programs in the United States. It showed that students who continued to participate in BEST for more than a year showed significant improvement in math and reading (Goldschmidt, \& Huang, 2007). Another study also showed that the length of youths' involvement affected the outcome of after-school program (Fredricks, et al., 2017).

\section{Needs Analyses of English Education}

For effective English education, learners' motivation and awareness of the importance of English as well as an appropriate English curriculum are required. In addition, in order to organize an appropriate English curriculum, needs of learners must be reflected. Accordingly, an educational method must be implemented. Recently, studies on learner's needs have been actively conducted because learner's needs analysis has become an important factor in determining the content and method of education.

Needs analyses began in the field of language education as part of English for Specific Purposes (ESP) education. ESP has been active since the 1980s. It is distinguished from English for General Purpose (EGP), which aims to improve language ability to communicate in everyday life. ESP is based on the question of why learners want to learn a foreign language. It argues that the content and method of education should be determined by analyzing the situation in which English will be used and the needs of the learner. 
Pratt (1980) has stated that the function of needs assessment is to establish priorities after confirming the needs and finding out whether they are justified. Needs assessment may examine the needs of the learner as a whole, or it may address a single need in detail. Richards, Platt, and Weber (1985) have defined needs analysis as the process of prioritizing language needs of learners. Needs analyses should include both subjective opinions of learners and objective data obtained through interviews, questionnaires, tests, and class observation.

Hutchinson and Waters (1987) have also offer questionnaires, observations, collection of related data, interviews, and consultations as methods of need investigation. Among various methods, questionnaire survey is the most common for a large number of subjects, Subjects of needs analysis are mainly learners. Needs analysis for learners is a major factor for establishing a learner-centered curriculum.

Previous studies on needs analysis related to English education have been actively conducted for the reform of English curriculum at various universities (Ko, 2014; Kwon, 2012). Studies on needs of elementary and secondary school students for English education (Kang, 2006; Kim, 2005; Shin \&Kim, 2012; Lim, 2005; Jeon, 2014) and needs analysis for parents have also been reported (Son, 2014; Jeon, 2010). Jeon (2014) conducted surveys and interviews to investigate the needs of students, principals, English teachers, and parents for the English program of alternative schools. Results of that study suggest that it is necessary to reinforce communication-oriented classes, to organize different classes by grade, and to have teachers who can speak both English and Korean.

\section{Limitations}

This study has several limitations. Firstly, since this study targeted secondary school students living in the northern part of Seoul, it would be difficult to generalize results of this study to secondary school students nationwide due to regional characteristics. Further research on other regional centers is needed in the future. Secondly, students' reaction and attitudes to the program might vary according to characteristics of the instructor.

Currently, there is only one English teacher teaching at the community childcare center. The number of volunteers is constantly changing. Thus, satisfaction and needs of students may change accordingly. Thirdly, the questionnaire was developed based on class activities currently being used in the English program at one community childcare center. 
Future researches should use more sophisticated instruments. Lastly, the number of students in the community childcare center was small. In addition, there was a difference in the number of students by grade. Thus, it was difficult to reflect opinions of all students in a balanced way.

Despite these limitations, this study confirmed that the overall satisfaction with the after-school English program was high for both content and effectiveness. Since students' satisfaction has become a critical indicator of teaching quality, consequently the quality of educational institution, teachers could benefit from results of this research.

\section{CONCLUSION}

The goal of this study was to investigate the effectiveness of an after-school English program at a community childcare center in a region of Seoul, and to propose a specialized and quality program based on the study results. Students participating in the English program at community childcare centers are mainly secondary students who cannot afford private English lessons. Since the instructor mainly relies on volunteers, the content and method of the class are not consistent. They considerably depend on the instructor's competence. To provide high-quality and effective English lessons, it is necessary to have a formal teaching method so that students can be taught consistently and effectively even if the instructor changes.

The survey provided an opportunity for students to report their levels of satisfaction with the program. Results of this study indicate that students are satisfied with the English program at the community childcare centers overall and, that the performance of the lecturer can be categorized very well. This study provides insights into the need and direction of English education for students from low-income families. This study will serve as a basis of specialized and qualified English programs for low-income students' successful English learning, and facilitate the continuous improvement process.

\section{REFERENCES}

Behrman, J. R., Fan, S., Wei, X., Zhang, H., \& Zhang, J. (2020). After-School Tutoring, Household Substitution and Student Achievement: Experimental Evidence from 
Rural China. PIER Working Paper No. 20-004, available at http://dx.doi.org/10.2139/ssrn.3523203.

Brown, H. D. (2001). Teaching by Principles. Addison Wesley Longman, Inc.

Byun, S. H., \& Sim, K. S. (2016). The Study on the Factors Influencing on the Quality of Service of Community Child Care Center Workers: Focusing on Office Environment and Job Satisfaction. Korean Journal of Care Management. 21, 51-75.

Choi, K. H. (2013). A Study on the Needs and Satisfaction of Youth Programs According to the Types of Community Childcare Centers. Unpublished Master's Thesis, Ulsan University, Ulsan, Korea.

Ellis, R. (2013). Language Teaching Research \& Language Pedagogy. Wiley Blackwell.

Fredricks, J. A., Naftzger, N., Smith, C., \&Riley, A. (2017) Measuring Youth Participation, Program Quality, and Social and Emotional Skills in After-School Programs. After-School Programs to Promote Positive Youth Development, available at https://doi.org/10.1007/978-3-319-59132-2_3.

Goldschmidt, P., \& Huang, D. (2007). The Long-Term Effects of After-School Programming on Educational Adjustment and Juvenile Crime: A Study of The LA's BEST After-School Program. Los Angeles: University of California, Los Angeles, National Center for Research and Evaluation, Standards and Student Testing.

Hutchinson, T., \& Waters, A. (1987). English for Specific Purposes: A Learning-Centered Approach. Cambridge: Cambridge University Press.

Jeon, S. Y. (2014). Needs Analyses for English Program of Alternative School. Unpublished Master's Thesis. Chung-Ang University, Graduate School of Education, Seoul, Korea.

Jeon, Y. S. (2010). Analysis of Parents' Perception and Needs for Elementary English Education. Unpublished Master's Thesis. Hanyang University, Graduate School of Education, Seoul, Korea.

Kang, H. D. (2006). Need Assessment for Developing E-Learning Materials for Elementary Students. Primary English Education, 12(1): 143-168.

Kim, M. S., \& Choi, J. A. (2015). The Effect of a 'Traditional Play Program' on A Child's SelfEsteem A Social Competency In A Community Child Center. Korean Journal of Child Studies, 36:39-57. 
Kim, J. H. (2010). English Teaching/Learning Methods and the Use of Teaching Models: Focusing on English Education in Elementary and Secondary Schools. Gyeongin National University of Education, 30(2): 37-63.

Kim, Y. C. (2006). Current Status of Secondary English Education and Effective Improvement Plan for English Education. English Education, 33: 37-65.

Kim, H. D. (2005). A Study on the Needs of Elementary School English Learners. Primary English Education, 11(1): 59- 83.

Ko, M. H. (2014). Study on the Needs of College English Program Learner for English Learning Apps. English Education, 26(2): 149-171.

Kwon, S. Y., \& Yeoh, Y. J. (2016). Assessment of Foodservice and Cooking Program for Children Attending Community Child Centers in Korea. Journal of the East Asian Society of Dietary Life, 6:223-229.

Kwon, S. (2012). Study on the Ways of Improve College English Program. Journal of the English Teachers Association in Korea, 18(4): 211-235.

Lim, H. J. (2005). A Case Study of A Village for Experiencing English: Needs Analyses for Learners. Unpublished Master's Thesis. SookMyung Woman's University, Graduate School of Education, Seoul, Korea.

McDavid, L., Parker, L. C., Li, W., Bessenbacher, A., Randolph, A., Harriger, A., \& Harriger, B. (2020). The Effect of An In-School Versus After-School Delivery on Students' Social and Motivational Outcomes in A Technology-Based Physical Activity Program. International Journal of STEM Education. 7(28).

Mehta, S., Good, J., Sands, P., Yadav, A., Gretter, S. \& Levenhagen-Seeley, J. (2018). Impact of After-School Learning Programs on High School Girls' Confidence and Interest in Computing. Proceedings of Society for Information Technology \& Teacher Education International Conference: $p$ 372-378.

Palardy, G., \& Rumberger, R. W. (2008). Teacher Effectiveness in First Grade: The Importance of Background Qualifications, Attitudes, and Instructional Practices for Student Learning. Educational Evaluation and Policy Analysis - Educ Eval Policy Anal. 30: 111-140. 
Park, T. J., Park, H. W., \& Lee H. Y. (2010). How Does the Community Child Center Work? Content Analysis to Conceptualize Director's Experiences. Journal of the Korean Society of Child Welfare, 12 : 75-109.

Pratt, D. (1980). Curriculum Design and Development. New York: Harcourt Brace Jovanovich.

Richards, J., Platt, J., \& Weber, H. (1985). Longman Dictionary of Applied Linguistics. Harlow, Essex, England: Longman.

Shin, M. Y., \& Kim, N. K. (2012). Concept and Function Syllabus Design Based on Needs Analysis and Examples of Unit Composition by Grade - Focusing on Middle School English Course. Studies in English language and literature, 54(1): 217-253.

Son, B. R. (2014). Analysis of Parents' Perception and Needs for Private Kindergarten English Program. Unpublished Master's Thesis. SookMyung Woman's University, Graduate School of Education, Seoul, Korea.

Yoon, H. M., Cho, M. S., \& Oh, J. R. (2013). Problems of After-School Care Service Project and Future Policy Direction. Korean Journal of Local Government \& Administration Studies, 27(1), 181-203. 